\title{
BLACK SEA AND FRESHWATER FISH AS VALUABLE SOURCES OF VITAMIN $\mathrm{D}_{3}$
}

\author{
Diana Dobreva \\ Department of Chemistry, Medical University of Varna
}

\begin{abstract}
Fat soluble vitamins are essential nutrients in important biological processes in the human body. Vitamin $\mathrm{D}_{3}$ (cholecalciferol) promotes and enhances the absorption and metabolism of calcium and phosphorus in our body. Nowadays there is a plethora of evidence suggesting that, in addition to its important role in maintaining bone health, vitamin $\mathrm{D}$ is involved in the amelioration of cell ageing and prevention of cardiovascular diseases, diabetes, immune dysfunctions and some cancers. This article presents information about vitamin $D_{3}$ contents in a broad range of fish species available on Bulgarian local fish markets. The aim is to increase consumers' awareness and encourage them to eat fish.
\end{abstract}

Keywords: Bulgarian fish, cholecalciferol, fish tissue, health, RDI

\section{INTRODUCTION}

Vitamin $\mathrm{D}_{3}$ (cholecalciferol) is synthesized by living cells in the skin or ingested by consumption of high-fat animal tissues (16). The human organism produces it endogenously by means of sunlight irradiation $(4,13)$.

The biologically active form of vitamin $\mathrm{D}_{3}$ (as a hormone in the human body) is 1,25-dihydroxylated form (calcitriol). The hormonal functions of vitamin $\mathrm{D}_{3}$ include regulation of bone and muscle health (skeletal and heart), the immune system, regulation of insulin and glucose levels, calcium and phosphorus metabolism. It increases the absorption and deposition of calcium in the bones, helps convert inorganic phosphorus to organic, stimulates bone

\footnotetext{
Address for correspondence:

Diana A. Dobreva

Department of Chemistry, Faculty of Pharmacy

Medical University of Varna

55 Marin Drinov Str.,

9000 Varna, Bulgaria

e-mail: didobreva@gmail.com
}

Received: February 21, 2014

Accepted: April 3, 2014 growth, prevents muscle cramps and bone fractures $(5,13,23,28)$.

Sufficient amounts of vitamin $\mathrm{D}_{3}$ in the body have a proven effect against the development of various diseases and/or disorders. A number of studies have demonstrated the beneficial effect of cholecalciferol supplementation in the prevention of cardiovascular diseases, high blood pressure, diabetes type I and II, osteoporosis, multiple sclerosis $(11,12,13,28)$. Much discussed is the role of vitamin $\mathrm{D}_{3}$ in the prevention of cancer $(4,28)$.

Recommendations on the average daily intake of vitamins have been approved and implemented by healthcare organizations in many countries. They aimed at specific groups of individuals - by age and gender: infants and children (divided into subgroups according to age - months and years), adolescents, adults (three subgroups - women, men and over 65 years old), pregnant women and lactating women (2, 21).

It was found that people living in warm areas with more sunlight during the year do not need additional vitamin $\mathrm{D}$ supplementation. According to Holik et al., 1980, the required daily intake of vitamin $\mathrm{D}_{3}$ can be obtained by $30 \mathrm{~min}$ daily exposure to sunlight 
Diana Dobreva

of the skin of the shoulders unprotected by sunscreen products (12). Subsequent inclusion of cholecalcifer$\mathrm{ol}$ in the metabolism happens about three days after synthesis.

Recommendations for dietary intake of vitamin $\mathrm{D}_{3}$ in different countries vary considerably, considering different geographical locations. The recommended daily doses are significantly higher in the Nordic countries (Sweden, Denmark and Norway) while they are lower in the Mediterranean region (Italy and France) $(10,24)$.

Due to the fact that many studies have proven endemic vitamin $\mathrm{D}$ deficiency in the EU countries by 2011, healthcare organizations significantly increased the recommended quantities - $10 \mu \mathrm{g} /$ day of cholecalciferol supplementation (2). At present, the recommended daily intake of vitamin $\mathrm{D}_{3}$ in Bulgaria is twice lower (5 $\mu \mathrm{g} /$ day) (21).

Fish are traditionally viewed as key part of a healthy and balanced diet, because they are one of the best sources of vitamin $\mathrm{D}_{3}$. The main reason for this is that they consume enormous amounts of plankton, which is rich in precursors - previtamin $\mathrm{D}_{2}$ and $\mathrm{D}_{3}$. Because of this, many researchers have studied cholecalciferol content in different fish species and fish samples - caviar $(20,30)$, edible fish tissues $(14,30)$, liver $(14,30)$, gonads $(14,30)$, kidney $(14)$ and spleen (30).

Fat soluble vitamins needed for optimal human health are found in fish tissues, but their amounts vary considerably depending on the species, season and different representatives of a given fish species (23). Edible fish tissue provides a significant amount of the recommended daily intake (RDI) of vitamins $A$ and $E$, and especially vitamin $D_{3}$ for humans (18).

The American Heart Association and FAO/ WHO recommend at least two fish servings per week $(1,8)$. In Bulgaria, this advice was described in Foodbased Dietary Guidelines for Adults in Bulgaria (9), because, the consumption of fish is very low $(4.5 \mathrm{~kg}$ annual per capita) compared to the average European levels (23 kg annual per capita) (8).

This article examines the nutritional and health benefits of fish as a valuable source of vitamin $\mathrm{D}_{3}$ and presents useful information for these biologically active components for Bulgarian consumers.

\section{MATERIAL AND METHODS}

Samples of fish were purchased from Varna local fish market. The sample preparation was performed using the method of Dobreva et al. (7). The reversed phase high performance liquid chromatography (HPLC) was used for the vitamin analysis. The recovery rates were calculated utilizing the external standard method. The results were expressed as $\mu \mathrm{g}$ per $100 \mathrm{~g}$ wet weight ( $\left.\mu \mathrm{g} \cdot 100 \mathrm{~g}^{-1} \mathrm{ww}\right)$.

The data were analysed using Graph Pad Prism 5 software. The results were presented as means and standard deviations. Column statistics was used for the calculation of the means, standard deviations, and the coefficients of variation. An unpaired t-test was used to evaluate the differences between the means. Statistical significance was indicated at $\mathrm{p}<0.05$.

\section{RESULTS AND DISCUSSION}

Table 1 presents the vitamin $\mathrm{D}_{3}$ content in three marine (horse mackerel, turbot and garfish) and two freshwater (rainbow trout and common carp) fish species. Amounts are presented as micrograms per $100 \mathrm{~g}$ wet weight $\left(\mu \mathrm{g} \cdot 100 \mathrm{~g}^{-1} \mathrm{ww}\right)$. Tabular data shows that the values of vitamin $\mathrm{D}_{3}$ in the edible tissue of different fish species vary widely $-0.98 \div 19,7$ $\mu \mathrm{g} \cdot 100 \mathrm{~g}^{-1} \mathrm{ww}$ (Table 1).

Rainbow trout (11.4 $\left.\mu \mathrm{g} \cdot 100 \mathrm{~g}^{-1} \mathrm{ww}\right)$, horse mackerel $\left(15.7 \mu \mathrm{g} \cdot 100 \mathrm{~g}^{-1} \mathrm{ww}\right)$, turbot $\left(4.6 \mu \mathrm{g} \cdot 100 \mathrm{~g}^{-1} \mathrm{ww}\right)$ and garfish $\left(5.8 \mu \mathrm{g} .100 \mathrm{~g}^{-1} \mathrm{ww}\right)$ fillets have similar values for cholecalciferol. Also similar but significantly lower are values of vitamin $\mathrm{D}_{3}$ of carp $\left(1.1 \mu \mathrm{g} \cdot 100 \mathrm{~g}^{-1} \mathrm{ww}\right)$. Ostermeyer and Schmidt have shown vitamin $\mathrm{D}_{3}$ content in wet fillets of rainbow trout and common

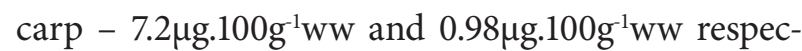
tively, which is in the same order as our data (Table 1).

The amounts of cholecalciferol was compared with the recommended daily intake (RDI) adopted in Bulgaria (21). Bulgarian dietary standards for average daily intake of fat soluble vitamins are close to those adopted in the European Union (2). An exception is the recommendation for daily intake of vitamin $\mathrm{D}_{3}$ (5 micrograms for adults in Bulgaria - twice lower than the daily reception in the EU).

The fillets of the presented fish species produced considerably higher amounts of vitamin $\mathrm{D}_{3}$ $(22.0-314.0 \%)$. Our results show that $100 \mathrm{~g}$ of raw 
Black sea and freshwater fish as valuable sources of vitamin $\mathrm{D}_{3}$

Table 1. Vitamin $D_{3}$ contents in edible fish tissue $\left(\mu g .100 g^{-1} w w\right)$

\begin{tabular}{lcl} 
Species & Vitamin $\mathrm{D}_{3}$ & References \\
Horse mackerel & $15.7 \pm 0.8^{*}$ & [Merdzhanova A. et al., 2013] \\
(Trachurus & $6.2 \pm 0.4$ & [Ostermeyer and Schmidt, 2005] \\
mediterraneus) & $8.7 \pm 0.5$ & [Dias M. et al., 2003] \\
& $2.0 \pm 0.07$ & [Whole Food Catalog] \\
Turbot & $4.6 \pm 0.5^{*}$ & [Stancheva M. et al., 2012] \\
(Psetta maxima) & $2.3 \pm 0.06$ & [Ostermeyer and Schmidt, 2005] \\
Garfish & $5.8 \pm 0.4^{*}$ & [Stancheva M. et al., 2012] \\
(Belone belone) & $5.0 \pm 0.2$ & [Danish Food Composition Databank] \\
Rainbow trout & $11.4 \pm 0.6^{*}$ & [Stancheva M. and Dobreva D.A., 2013] \\
(Oncorhynchus & $8.0 \pm 0.6$ & [J. Szlinder-Richert et al., 2011] \\
mykiss) & $19.7 \pm 0.9$ & [Kuhnlein H. et al., 2007] \\
& $9.7 \pm 0.7$ & [Lu Z. et al., 2007] \\
& $8.2 \pm 0.6$ & [Ostermeyer and Schmidt, 2005] \\
Common carp & $19.0 \pm 0.8$ & [Dias M. et al., 2003] \\
(Cyprinus carpio) & $1.1 \pm 0.1^{*}$ & [Stancheva M. and Dobreva D.A., 2013] \\
& $7.46 \pm 0.5$ & [Szlinder-Richert J. et al., 2011] \\
\hline
\end{tabular}

* - own data (Bulgarian freshwater and Black Sea fish)

rainbow trout and grey mullet fillets provide about $228 \%$ and $314 \%$ vitamin $\mathrm{D}_{3} \mathrm{RDI}$, respectively. The average value in the table data $\left(8,0 \mu \mathrm{g} .100 \mathrm{~g}^{-1} \mathrm{ww}\right)$ represents a significant amount, compared to the RDI of this vitamin - $80 \%$ of RDI for EU countries and $160 \%$ of RDI for Bulgaria.

\section{CONCLUSION}

Fish are a rich dietary source of fat soluble vitamin $\mathrm{D}_{3}$. The content of this micronutrient varies considerably depending on the fish species. The present study provides useful information about cholecalciferol content in some traditionally consumed fish species in Bulgaria. Most of the Bulgarian fish species provide considerable amounts of vitamin D3 - a quantity almost twice as high as that of the RDI for Bulgaria. Based on the presented information we can conclude that the edible fish tissue of these species is a very good source of vitamin $\mathrm{D}_{3}$.

\section{REFERENCES}

1. American Heart Association. Heart Attack and Related Diseases. Washington, DC; 2004. Available from: http://www.americanheart.org/.

2. Catharine R, Christine LT, Ann LY, Heather B. Dietary Reference Intakes for Calcium and Vitamin D. Institute of Medicine (US). Nat Acad Press; 2011.
3. Danish Food Composition Databank, Department of Nutrition, National Food Institute, 2009. Available from: http://www.foodcomp.dk/v6/fcdb_details.asp?FoodId=0082.

4. De Wever O, Mareel M. Role of tissue stroma in cancer cell invasion. J Pathol. 2003;200:429-47.

5. DeLuca HF. The vitamin D story: a collaborative effort of basic science and clinical medicine. FASEB. 1988; 2:224-36.

6. Dias, M.G., M.V. Sanchez, H. Bartolo, L. Oliveira. Vitamin content of fish and fish products consumed in Portugal, Electron. - J. Environ. Agric. Food Chem., 2, 2003, 1579-4377.

7. Dobreva, D.A.; B. Galunska, M. Stancheva. Liquid chromatography method for the simultaneous quantification of fat soluble vitamins in fish tissue. - Scr Sci Med, 43, 2011, 276-279.

8. FAO/WHO. Food and Nutrition. 2010; 91. Available from: http://www.fao.org/docrep/013/i1953e/ i1953e00.pdf

9. Food Based Dietary Guidelines for Adults in Bulgaria. Ministry of Health, National Center of Public Health Protection With the support of WHO Regional Office for Europe. Sofia;2006:1-41. Available from: http://ncpha.government.bg/files/hranene-en.pdf 
10. Freisling H, Fahey MT, Moskal A, Ocké MC, Ferrari $\mathrm{P}$, Jenab M, et al. Region-specific nutrient intake patterns exhibit a geographical gradient within and between European countries. J Nutr. 2010;140:1280-6.

11. Heaney RP. Nutrition and chronic disease. Mayo Clin Proc. 2006;81:297-9.

12. Holick MF, McLaughlin JA, Clark MB, Holick SA, Anderson RR, Blank IH, et al. Photosynthesis of previtamin $\mathrm{D}_{3}$ in human and the physiologic consequences. Science. 1980;210:203-5.

13. Jones G, Strugnell S, DeLuca HF. Current understanding of the molecular actions of vitamin D. Physiol Revs. 1998;78:1193-231.

14. Kandemir S. The Fatty Acid Composition and Cholesterol and Vitamin Contents of Different Muscles of Esox lucius (Linnaeus, 1758) Living in Lake Ladik. J Anim Vet Adv. 2010;9:1179-90.

15. Kuhnlein HV, Barthet V, Farren A, Falahi E, Leggee D, Receveur O, et al. Vitamin A, D and E in Canadian Arctic traditional food and adult diets. J Food Comp Anal. 2006;19:495-506.

16. Masterjohn C. From Seafood to Sunshine A New Understanding of Vitamin D Safety. Wise Traditions, Fall 2006.

17. Merdzhanova A, Stancheva M, Dobreva DA, Makedonski L. Fatty acid and fat soluble vitamins composition of raw and cooked Black Sea horse mackerel. Ovid Univ An Chem. 2013;24:27-34.

18. Murray J, Burt JR. The Composition of Fish. Torry Res Stat, FAO, Torry Advisory Note. 2001;38. Available from: http://www.fao.org/wairdocs/tan/ x5916E/x5916e00.htm

19. NAFA, National Strategic Plan for Fisheries and Aquaculture 2007-2013. Ministry of Agriculture and Forestry, National Agency for Fisheries and Aquaculture. Sofia: 2007. Available from: http:// www.mzgar.government.bg/mz_eng/default.asp.

20. Olgunoğlu İA, Olgunoğlu MP. Concentrations of metal contaminants, vitamin and mineral in waxed caviar from Mugil cephalus (L.,1758). Afr J Agric Res. 2011;6:1041-6.
21. Ordinance №23/19.07.2005 on the physiological feeding of population. Available from: http:// bg.wikipedia.org/wiki/Физиологични_норми_ за_хранене\#сіte_note-echo-9

22. Ostermeyer U, Schmidt T. Vitamin D and provitamin D in fish. Eur Food Res Technol. 2005;2:53-9.

23. Painter FM. Vitamin D. Thorne Res, Altern Med. 2008;13.

24. Paturi M, Tapanainen $H$, Reinivuo $H$, Pietinen $P$. The National Findiet 2007 Survey. Helsinki: Nat Publ Health Inst; 2008.

25. Stancheva M, Dobreva DA, Galunska B. Retinol, cholecalciferol and alpha-tocopherol contents of Bulgarian Black Sea fish species. Ovid Univ An Chem. 2012;23:31-4.

26. Stancheva M, Dobreva DA. Bulgarian Marine and Freshwater Fishes as a Source of Fat-Soluble Vitamins for a Healthy Human Diet. Foods. 2013;2:332-7.

27. Szlinder-Richert J, Usydus Z, Malesa-Ciecwierz M, Polak-Juszczak L, Ruczynska W. Marine and farmed fish on the Polish market: Comparison of the nutritive value and human exposure to PCDD/Fs and other contaminants. Chemosphere. 2011;85:1725-33.

28. Vasquez A, Manso G, Cannell J. The clinical importance of vitamin D (cholecalciferol): a paradigm shift with implications for all healthcare providers. Altern Ther. 2004;10.

29. Whole Food Catalog. 2007. Available from: http:// wholefoodcatalog.info/food/horse_mackerel(raw)/

30. Yamamoto Y, Fujisawa A, Hara A, Dunlap WC. An unusual vitamin $\mathrm{E}$ constituent (a-tocomonoenol) provides enhanced antioxidant protection in marine organisms adapted to cold-water environments. Proc Natl Acad Sci USA. 2001;98:13144-8. 